\title{
On the Innovation of High School Ideological and Political Education under the Background of One Core, Four Layers and Four Wings
}

\author{
Guanghua Wan \\ Changning Middle School, Yibin 644300, Sichuan Province, China
}

\begin{abstract}
With the introduction of the new college entrance examination evaluation system, great changes have taken place in the function, purpose and significance of the college entrance examination. In addition to evaluating students' learning achievements, it also undertakes the important function of educating people and morality, which also urges high school teachers to take educating people as the main teaching direction. As far as the ideological and political education in senior high school is concerned, there are many disadvantages in the traditional teaching mode, which leads to the students' low learning enthusiasm, and the inability to deeply understand the connotation of ideological and Political Education, so that the discipline which should have the most educational function can not fully play its due role. Therefore, the ideological and political education in senior high school should make bold innovation, so as to quickly adapt to the new evaluation system. This paper makes an in-depth study on how to innovate the ideological and political education in senior high school under the background of one core, four layers and four wings, and provides some specific measures.
\end{abstract}

Key words: One core; Four layers and four wings; Senior high school; Ideological and Political Education

Publication date: December, 2020

Publication online: 31 December, 2020

"Corresponding author: Guanghua Wan, 1581152934 @qq.com

China is in the deepening period of reform and opening up, in urgent need of a large number of new era talents with correct values and world outlook, which requires the education system to play the role of moral education, cultivate high-level talents in line with the national and social development. High school education is the key period of success, students' scientific and cultural knowledge level will be greatly improved, ideological and moral consciousness will gradually form, and gradually generate a set of personal evaluation criteria to look at the world. The introduction of the new college entrance examination evaluation system requires ideological and political teachers to guide students to correctly view the relationship between what they have learned and the real world, and think about the problems faced by society and the country according to what they have learned, so as to lay a good foundation for serving the country and society in the future, so that students can unswervingly follow the party, and deeply implement the national development policy.

1 New college entrance examination evaluation system of "one core, four layers and four wings"

1.1 "One core" is the basis to answer the question of "why to test" in college entrance examination.

"One core" is the new college entrance examination evaluation system, which mainly includes moral education, service selection and oriented teaching. It expounds the purpose, function and significance of college entrance examination. Moral education is the fundamental purpose of education, no matter how the students' academic performance, teachers and schools 
hope that students can become a useful person to society; The essence of college entrance examination is a selection system. Students with different learning levels are bound to enter different levels of education system, which also affects the future development of students; Guided teaching is the meaning, the college entrance examination results reflect the students' learning achievements in the whole stage of basic education, and only with the college entrance examination as the final benchmark in primary and secondary education, can students get good results in the new college entrance examination evaluation system.

\section{2 "Four levels" is the content, which answers the question of "what to test" in college entrance examination.}

The "four levels" mainly include the necessary knowledge, key ability, subject quality and core value, including both knowledge assessment and quality assessment. In the stage of basic education, knowledge education and method education are the main contents. Students should learn a lot of general knowledge, understand the learning methods and research methods of various disciplines, so as to have a systematic understanding of the achievements of human thought and civilization. In the process of learning knowledge, students are not simply memorizing, but constantly thinking and solving new problems in their minds, constantly applying new methods in reality, and generating new value understanding in the process of learning, so as to have a correct view on the development of society and the world. The new college entrance examination evaluation system includes the assessment contents of knowledge, ability, quality and value, which is very comprehensive and targeted, and can better play the role of education.

\section{3 "Four wings" is the requirement to answer the question of "how to test".}

"Four wings" is the specific requirements for the form of college entrance examination, which mainly includes four aspects: basic, comprehensive, applied and innovative. The basic and comprehensive requirements are in line with the characteristics of basic education teaching content. After all, the purpose of basic education is to enable students to have a broad-based understanding of the knowledge of various disciplines, and does not require students to conduct in-depth research on the knowledge of a certain discipline. The application and innovation is to attach importance to the influence of basic education on students' thinking. The basic education stage runs through the whole period of students' thinking development, and has an important impact on the development of students' thinking ability, innovation ability, observation ability, analysis ability and other aspects. Therefore, the new college entrance examination system also emphasizes these aspects, and requires teachers to pay attention to these aspects in the teaching process, In addition to spreading a lot of knowledge, we should pay more attention to the growth of students' thinking, so that students can master efficient and reasonable way of thinking.

\section{Innovative measures of high school Ideological and Political Education under the background of "one core, four layers and four wings"}

\subsection{Carry out information teaching, let students master the necessary knowledge}

High school political content involves politics, rule of law, economy, culture and many other aspects, the knowledge is fragmentary and difficult to understand. It is difficult for students to fully understand the connotation and significance through the text, so they can not write the answers that meet the requirements of the college entrance examination. Therefore, teachers should innovate teaching methods, turn abstract ideological and political knowledge into concrete, so that students can fully understand and master the necessary ideological and political knowledge, so that students can logically deduce relevant knowledge points according to the problems when thinking about problems, so as to grasp the key points of assessment and make targeted answers. Information teaching has been widely used in various disciplines. Ideological and political teachers can use information technology to carry out ideological and political teaching. By showing the operation of ideological and political content in social, economic, cultural and other fields, students can have a profound and complete understanding of Ideological and political knowledge. For example, many students are unable to clearly distinguish the specific responsibilities and relationships between the administrative organs and the procuratorial organs 
in our country. I use multimedia teaching to make a targeted distinction between the two organs in the form of animation, so that students can understand that there is only supervision relationship, not restriction or subordination relationship between the administrative organs and the procuratorial organs, and have a detailed understanding of the specific responsibilities of the two organs. Animation is very suitable for the concrete expression of abstract concepts or abstract relations, which can effectively reduce the students' understanding pressure and make students understand complex concepts simply, so that students can firmly grasp the basic knowledge and use it flexibly in the college entrance examination.

\subsection{Developing topic based teaching to improve students' key abilities}

The content of Ideological and Political education is closely related to real life, and the political questions of college entrance examination also involve the analysis of real events. Therefore, the key ability of political science is to transform real problems into ideological and political problems, so that students can grasp the connection between ideological and political ideas and real problems. Therefore, teachers can carry out topic based teaching, let students discuss practical problems, and turn them into political, economic or social issues, so as to carry out rational and objective analysis, and use the content of ideological and political textbooks to debate. This not only improves students' critical thinking ability, but also enables students to deepen their understanding of ideological and political theories and concepts in the process of discussion, and connect them with practical problems, so as to see political ideas concretely, realistically and in daily life. For example, some students don't have a deep understanding of the concept of community of human destiny, and they can't connect the concept with the development of human reality. I will take students to understand the main problems that affect human society, such as virus, poverty, food, climate and so on, and let students take these problems as topics to discuss the specific role and significance of the concept of community of human destiny in solving these problems significance. In this way, students can combine ideological and political content with practical problems for thinking, and understand the theoretical guiding role of ideological and political content, and there are many ways to solve these problems, but only the concept of community of human destiny plays a guiding role in guiding people to unite and carry out practical action.

\subsection{Carrying out case teaching and strengthening students' subject quality}

Subject accomplishment is the embodiment of students' complete mastery of the course content, and the accomplishment of political discipline is mainly reflected in the transformation of ideology. Only when students have the scientific spirit and the awareness of the rule of law, and actively participate in social construction, and have a strong sense of identity with China's political system, can they understand the profound connotation of each semester content of ideological and political course. Teachers can use case teaching method, so that students can gradually master the required qualities of political science in the process of learning real cases, so that students can always feel the role of ideological and political ideas in the process of life development, and make correct life choices under the guidance of relevant ideas. For example, when explaining China's economic system, students don't know much about the practical application and manifestation of China's economic system. In view of the characteristics of China's "public ownership economy as the main body and multi ownership economy developing together", I give examples to state-owned economy, private economy, individual economy, foreign capital economy and other economic forms, so that students can understand the differences and differences In reality, after entering the society, students can have a general understanding of China's economic situation and make corresponding career adjustment according to the development and upgrading of China's economic structure.

\subsection{Developing practice teaching and cultivating students' core values}

Socialist theory is an important ideological and political content, but students' understanding of it is generally not high, they can not accurately understand the development process of socialism and the superiority of the socialist system, and they do not have a deep understanding of the important connotation and significance of society, so it is difficult to cultivate students' core values. Therefore, teachers can carry out practical teaching, let students 
practice socialist thought through action, and learn to understand socialism in practice, so as to connect the development of the country and the nation with personal development, establish a correct outlook on life and values, and make continuous efforts for the great rejuvenation of the Chinese nation. Teachers can take students to listen to the news broadcast, organize reading meetings and lectures, so that students can learn the thought of socialism with Chinese characteristics in the new era on the premise of understanding the process of socialist development, keep up with the development of the times, and understand the new connotation and significance of the socialist system in the new era. Through practical teaching, it also helps students to have a systematic understanding of Ideological and political knowledge, and realize the connection between the various parts of Ideological and political knowledge, so that they can have a firm position and correct attitude in the face of practical problems.

\section{Conclusion}

The new college entrance examination evaluation system is conducive to the realization of educational equity, and can effectively promote the development of quality education. Through innovative teaching methods, teachers combine ideological and political content with practical problems in teaching, so that students can fully grasp the core connotation and significance of ideological and political knowledge, and according to the requirements of the new college entrance examination evaluation system, greatly improve the students' quality and ability in all aspects To expand the students' ideological and political knowledge reserves, and help students establish a correct outlook on life, values and world outlook, so as to cultivate a new era of talents with all-round development of morality, intelligence, sports, beauty and labor for the society and the country.

\section{References}

[1] Wei GJ. Review ideas of political college entrance examination based on the evaluation system of "one body, four layers and four wings" -- Interpretation of the revised syllabus of political college entrance examination in 2017 and suggestions for preparation [J]. Basic education curriculum, 2017, (5): 62-68.

[2] Chen CK. Practice and thinking of innovative education in ordinary high schools under the background of new college entrance examination -- a case study of Wenling middle school in Zhejiang Province [J]. New curriculum review, 2016, (007): 60-67.

[3] Xie ZR. Exploration of the core literacy oriented political issue teaching method in senior high school $[\mathrm{J}]$. Chinese loose leaf selections (Teacher Edition), 2020, (19): 118-119.

[4] Lei SJ. An analysis of the evaluation methods of the core literacy of high school political discipline under the concept of moral cultivation -- A case study of Guangxi literature comprehension politics volume in the college entrance examination in 2017 [J]. Guangxi Education (Secondary Education), 2018(2): 159-161. 